\title{
STUDI MENGENAI STATUS GIZI BALITA
}

\author{
Syarifa Amalia Alhamid ${ }^{1}$, Bunga Tiara Carolin ${ }^{2}$, Rosmawaty Lubis ${ }^{3}$ \\ 1,2,3Program Studi Kebidanan, Fakultas IImu Kesehatan, Universitas Nasional Jakarta \\ 1 email : syarifaalhamid562@gmail.com \\ 2email bunga.tiara@civitas.unas.ac.id \\ 3email rosma.lubis@gmail.com \\ *korespondensi
}

\section{ABSTRACT A STUDY OF THE NUTRITIONAL STATUS OF TODDLERS}

Background: Nutrition is a very important part of the growth and development of toddlers which is related to health and intel

ligence. In 2019, the prevalence of malnutrition in Bula District Seram was 10.2\%, malnutrition was 4.3\% and over nutrition was $5.1 \%$, where the incidence rate was increased from the previous year.

Objective: To determine the factors related to the nutritional status of toddlers in the Bula Health Center, East Seram District, Maluku Province.

Methodology: This study is a cross sectional correlation study. The samples in the study were all women who had children aged 1-5 years who visited the Bula Health Center, East Seram Regency, Maluku Province in 2020 which consisted 76 toddlers. The research instrument was a questionnaire, data analysis using the chi square test.

Results: the results showed that malnourished toddlers were 59.2\%, women with poor knowledge were $76.3 \%$, women who had low level education were $63.2 \%$, women with low family income were $72.4 \%$, women who did not work were $55.3 \%$, women who did not provide breast feeding was $71.1 \%$ and toddlers who had the history of infectious diseases were $71.1 \%$. The bivariate results obtained knowledge $(p=0,022)$, education $(p=0,048)$, income $(p=0,002)$, occupation $(p=0,088)$, history of breastfeeding $(p=0,001)$ and a history of infectious diseases $(p=0,020)$.

Conclusions: There is a relationship between knowledge, education, family income, history of breastfeeding, and a history of infectious diseases with the nutritional status of toddlers.

Suggestions: It is hoped that health workers can provide education about nutrition to mothers, so that they could pay more attention to the nutritional status of their toddlers.

Keywords: Toddler, Bula Health Centre, Nutritional Status

\section{ABSTRAK}

Latar belakang: Gizi menjadi bagian sangat penting dalam pertumbuhan dan perkembangan balita yang didalamnya memiliki keterkaitan yang erat hubungannya dengan kesehatan dan kecerdasan. Pada tahun 2019 di Puskesmas Bula Kabupaten Seram prevelnsi gizi kurang sebesar 10,2\%, Gizi Buruk 4,3\% dan gizi lebih 5,1\% dimana angka kejadian ini menigkat dari tahun sebelumnya.

Tujuan: Mengetahui faktor yang berhubungan dengan status gizi balita di Wilayah Puskesmas Bula Kabupaten Seram Bagian Timur Provinsi Maluku.

Metodologi: Penelitian ini adalah penelitian korelasi dengan cross sectional. Sampel dalam penelitian adalah semua ibu yang mempunyai balita usia 1-5 tahun yang berkunjung ke Puskesmas Bula Kabupaten Seram Bagian Timur Provinsi Maluku tahun 2020 berjumlah 76 balita. Instrumen penelitian adalah kuesioner, analisis data menggunakan uji chi square.

Hasil penelitian: Pada hasil didapatkan balita gizi kurang $(59,2 \%)$, ibu berpengetahuan kurang baik $(76,3 \%)$, ibu berpendidikan rendah $(63,2 \%)$. pendapatan keluarga rendah $(72,4 \%)$, ibu yang tidak berkerja $(55,3 \%)$, ibu yang tidak memberikan ASI $(71,1 \%)$ dan balita yang memiliki riwayat penyakit infeksi $(71,1 \%)$. Hasil bivariat didapatkan pengetahuan $(p=0,022)$, pendidikan $(p=0,048)$, pendapatan $(p=0,002)$, pekerjaan $(p=0,088)$, riwayat $A S I(p=0,001)$ dan riwayat penyakit infeksi $(p=0,020)$.

Kesimpulan: Terdapat hubungan antara pengetahuan, pendidikan, pendapatan keluarga, riwayat ASI, dan riwayat penyakit infeksi dengan status gizi balita.

Saran: Diharapkan kepada petugas kesehatan dapat memberikan edukasi mengenai gizi kepada ibu agar lebih memperhatikan status gizi balitanya.

Kata Kunci: Balita, Puskesmas Bula, Status gizi 


\section{PENDAHULUAN}

Gizi menjadi bagian sangat penting dalam pertumbuhan dan perkembangan balita yang didalamnya memiliki keterkaitan yang erat hubungannya dengan kesehatan dan kecerdasan. Pemberian gizi yang kurang baik terutama terhadap anak-anak, akan menurunkan potensi sumber daya pembangunan masyarakat (Cakrawati \& Mustika, 2012).Menurut Laporan Global Nutrision pada tahun 2017 menunjukan masalah status gizi di dunia diantaranya prevelensi wasting (kurus) 52 juta balita (8\%) stunting (pendek) 115 juta balita $(23 \%)$ dan overweight di dunia tahun 2016 berdasarkan lingkup kawasan WHO yaitu Afrika 11,3 juta balita (17,3\%), Amerika 1,3 juta balita (1,7\%), Asia Tenggara 48 juta balita $(26,9 \%)$, Eropa 0,7 juta balita $(1,2 \%)$, sedangkan secara global didunia prevalensi anak usia dibawah lima tahun yang mengalami underweight yaitu $14 \%$ (94,5 juta ) (WHO, 2017).

Data Profil Kesehatan Indonesia 2017, Provinsi Maluku mempunyai Prevalensi Gizi buruk pada balita sebanyak $2,7 \%$ dan prevelensi kurang sebanyak $11,7 \%$ pada tahun 2018. Sedangkan prevalensi status gizi balita kategori sangat pendek sebanyak 10,0\% dan kategori pendek sebanyak 10,1 (Kementrian Kesehatan RI, 2018). Hasil pemantauan status gizi dinas kesehatan Profinsi Maluku di ketahui bahwa jumlah balita secara keseluruhan yang berstatus gizi buruk di Maluku pada tahun 2018 sebanyak 39 balita $(0,52 \%$, balita gizi kurang sebanyak 245 orang $(11,62 \%)$, dan gizi lebih sebesar $(1,67 \%)$. Prevelensi balita termasuk kategori pendek sebanyak $12,61 \%$ dan sangat pendek $7,44 \%$ (Dinas Kesehatan Provinsi, 2018). Pada tahun 2016 Dinas Kesehatan Kabupaten Ambon mencatat sekitar balita gizi buruk sebnayak 10 balita dan menurun pada tahun 2017 menjadi 6 balita. Prevelensi balita gizi kurang 122 balita pada tahun 2017 dan pada tahun 2019 meningkat menjadi 240 balita. (Dinas Kesehatan Ambon 2020).

Upaya pemerintah dalam hal menurunkan masalah status gizi di Indonesia adalah dengan salah satu Program kebijakan Nasional dalam perbaikan gizi yang tertaung dalam undang-undang nomor 36 tahun 2009. Bahwa upaya perbaikan gizi di tunjukan untuk peningkatan gizi perorangan dan masyarakat. Selanjutnya dalam rangka percepatan perbaikan gizi pemerintah mengeluarkan Peraturan Presiden Nomor 42 tahun 2013 tentang gerakan Nasional Percepatan Perbaikan Gizi yang fokus pada 1.000 hari pertama kehidupan (HPK). (Kementrian Kesehatan, 2012).

Data yang diperoleh dari Puskesmas Bula Kabupaten Seram 2018 prevelensi status gizi anak balita menurut $(\mathrm{BB} / \mathrm{U})$. (TB/U) dan $\mathrm{BB} / \mathrm{TB}$, yaitu prevelnsi gizi kurang sebesar 9,7\%, Gizi Buruk 3,9\% dan gizi lebih $4,1 \%$ prevelensi pendek $8,6 \%$ dan sangat pendek $3,1 \%$ prevelensi kurus $12 \%$ sangat kurus $0,8 \%$ dan gemuk $3,2 \%$. Sedangkan pada tahun 2019 prevelensi status gizi anak balita menurut (BB/U). (TB/U) dan BB/TB, yaitu prevelnsi gizi kurang sebesar 10,2 \%, Gizi Buruk 4,3\% dan gizi lebih $5,1 \%$ prevelensi pendek $10,1 \%$ dan sangat pendek $10,6 \%$ prevelensi kurus $17 \%$ sangat kurus $0,2 \%$ dan gemuk 4,36\%. Artinya bahwa ada peningkatan jumlah kasus status gizi balita di Wilayah Kerja Puskesmas Bula (Puskesmas Bula, 2020).

Berdasarkan data di atas yang menunjukan bahwa keadaan satatus gizi di Indonesia masih sangat memprihantikan sedangkan sudah banyak program yang dilakukan oleh pemerintah tapi belum menujukan penurunan angka kejadian status gizi pada balita dan untuk hasil penelitian yang dilakuakan sebelumnya menujukan ada banyak faktor yang mempengeruhi status gizi balita yang ada di Indonesia. Untuk itu peneliti tertarik dengan status gizi pada balita untuk dijadikan sebagai bahan pertimbahan penelitian dengan judul "Studi Mengenai Status Gizi Balita Di Wilayah Puskesmas Bula Kabupaten Seram Bagian Timur Provinsi Maluku"

\section{METODE PENELITIAN}

Desain Penelitian ini adalah jenis penelitian analitik dengan pendekatancross sectional. Tempat penelitian berada di Wilayah Puskesmas Bula Kabupaten Seram Bagian Timur Provinsi Maluku. Waktu penelitian dilaksanakan pada bulan Maret Juli 2020. Populasi dalam penelitian ini adalah semua ibu yang mempunyai balitausia 1-5 tahun berjumlah 76 anak balita. Teknik pengambilan sampel menggunakan total sampling. Instrumen penelitian menggunakan kuisioner yang sudah teruji validitas dan reliabilitasnya.Penyebaran kuisioner menggunakan google form.Analisis data menggunakan menggunakan uji Chi-Square.

\section{HASIL PENELITIAN}

Diketahui dari tabel 1 sebagian besar ibu- ibu yang mempunya balita dengan gizi kurang sebanyak 45 balita $(59,2 \%)$, ibu berpengatuan kurang baik sebanyak 58 ibu $(76,3 \%)$ ibu berpendidikan rendah sebanyak 48 ibu $(63,2 \%)$ pendapatan rendah sebnyak 55 ibu $(72,4 \%)$, ibu yang tidak berkerja sebanyak 42 ibu (55,3\%), ibu yang tidak memberikan ASIsebanyak 54 ibu $(71,1 \%)$ balita yang memiliki riwayat penyakit infeksi sebanyak 54 orang $(71,1 \%)$.

Tabel 1. 
Distribusi Frekuensi Faktor status Gizi Balita

\begin{tabular}{lcc}
\hline \multicolumn{1}{c}{ Variabel } & Frekuensi & Persentase \\
\hline Status Gizi & & \\
Gizi kurang & 45 & 59,2 \\
Gizi baik & 31 & 40,8 \\
$\begin{array}{l}\text { Pengetahuan } \\
\text { Kurang }\end{array}$ & & \\
Baik & 58 & 76,3 \\
Pendidikan & 18 & 23,7 \\
Rendah & & \\
Tinggi & 48 & 63,2 \\
Pendapatan & 28 & 36,8 \\
Keluarga & & \\
Rendah & & \\
Tinggi & 55 & 72,4 \\
Pekerjaan & 21 & 27,6 \\
Tidak bekerja & & \\
Bekerja & 42 & 55,3 \\
Riwayat ASI & 34 & 28,9 \\
Tidak & & \\
Ya & 54 & 71,1 \\
Riwayat Penyakit & 22 & 28,9 \\
Infeksi & & \\
Ada & & \\
Tidak ada & 54 & 71,1 \\
\hline
\end{tabular}

Pada tabel 2 menunjukan bahwa ibu yang berpengetahun kurang yang balitanya mengalami gizi kurang sebanyak 39 orang $(67,2 \%)$, lebih rendah dengan ibu yang berpengetahuan baik yang mengalami kurang gizi sebanyak 6 orang $(33,2 \%)$. Hasil uji stastistik di peroleh $p$ value 0,022 yang artinya ada hubungan yang bermakna antara pengetahuan ibu dengan status gizi balita.lbu yang berpendidikan rendah yang bayinya mengalami gizi kurang sebanyak 33 balita $(68,8 \%)$, sedangakan ibu yang berpendidikan tinggi dan bayinya mengalami gizi kurang sebanyak 12 balita $(42,9 \%)$. Hasil uji stastistik di peroleh $p$-value 0,048 menunjukan adanya hubungan yang bermakna antara pendidikan dengan status gizi balita.Pendapatan keluarga rendah yang mengalami gizi kurang sebanyak 39 orang $(70,9 \%)$, sedangkan tingginya pendapatan keluarga yang mengalami gizi kurang sebanyak 6 orang $(28,6 \%)$ Hasil uji stastistik di peroleh $p$-value 0,020 yang artinya bahwa ada hubungan yang bermakna antara pendapatan keluarga dengan status gizi balita.

Berdasarkan tabel 2 juga untuk ibu yang bekerja dan balitanya mengalami gizi kurang sebanyak 29 orang $(64,4 \%)$, sedangkan ibu yang tidak bekerja dan balitanya mengalami gizi kurang sebanyak 16 orang $(35,6 \%)$. Hasil uji stastistik di peroleh $p$-value 0,088 yang artinya bahwa tidak ada hubungan yang bermakna antara pekerjaan dengan status gizi balita.lbu yang tidak memberikan ASI dan balitanya mengalami gizi kurang sebanyak 39 orang $(72,2 \%)$ sedangkan ibu yang memberikan ASI dan balita mengalami gizi kurang sebanyak 6 orang (27,3\%). Hasil uji stastistik di perolehp-value0,001 yang artinya bahwa ada hubungan yang bermakna antara riwayat ASI dengan status gizi balita,Balita yang pernah menderita riwayat penyakit infeksi serta dirawat di rumah sakit 3-4 kali dapat menyebabkan gizi kurang pada balita sebanyak 37 orang $(68,4 \%)$, sedangkan yang tidak pernah menderita riwayat penyakit infeksi yang menyebabkan status gizi kurang pada balita sebanyak 8 orang $(36,4 \%)$. Hasil uji stastistik di peroleh $p$-value 0,020 menunjukan adanya hubungan yang bermakna antara riwayat penyakit infeksi dengan status gizi balita.

Tabel 2.

Hubungan Karakterristik responden dengan status gizi balita

\begin{tabular}{|c|c|c|c|c|c|c|c|}
\hline \multirow{3}{*}{ Variabel } & \multicolumn{4}{|c|}{ Status Gizi Balita } & \multirow{2}{*}{\multicolumn{2}{|c|}{ Jumlah }} & \multirow{3}{*}{$p$ value } \\
\hline & \multicolumn{2}{|c|}{ Gizi Kurang } & \multicolumn{2}{|c|}{ Gizi Baik } & & & \\
\hline & $f$ & $\%$ & $f$ & $\%$ & $f$ & $\%$ & \\
\hline \multicolumn{8}{|l|}{ Pengetahuan } \\
\hline Kurang & 33 & 67,2 & 19 & 32,8 & 58 & 76,3 & \multirow{3}{*}{0,022} \\
\hline Baik & 12 & 33,2 & 12 & 66,7 & 18 & 23,7 & \\
\hline \multicolumn{7}{|l|}{ Pendidikan } & \\
\hline Rendah & 36 & 68,8 & 15 & 31,3 & 48 & 63,2 & \multirow{3}{*}{0,048} \\
\hline Tinggi & 46 & 42,9 & 16 & 57,1 & 28 & 36,8 & \\
\hline \multicolumn{7}{|l|}{ Pendapatan Keluarga } & \\
\hline Rendah & 39 & 70,9 & 16 & 41,9 & 42 & 74,4 & \multirow{3}{*}{0,002} \\
\hline Tinggi & 6 & 28,6 & 15 & 58,1 & 34 & 27,6 & \\
\hline \multicolumn{7}{|l|}{ Pekerjaan } & \\
\hline Ya & 29 & 64,4 & 13 & 9,1 & 47 & 55,3 & \multirow{2}{*}{0,088} \\
\hline Tidak & 16 & 35,6 & 18 & 7,1 & 51 & 44,7 & \\
\hline
\end{tabular}


Riwayat ASI

\begin{tabular}{lccccccc} 
Tidak & 39 & 72,2 & 15 & 27,8 & 45 & 71,1 & 0,001 \\
Ya & 6 & 27,3 & 16 & 72,7 & 22 & 28,9 & \\
$\begin{array}{l}\text { Riwayat Penyakit infeksi } \\
\text { Pernah }\end{array}$ & 37 & 68,5 & 17 & 31,5 & 54 & 71,1 & \\
Tidak & 8 & 36,4 & 14 & 63,6 & 22 & 28,9 & 0,020 \\
\hline
\end{tabular}

\section{PEMBAHASAN}

Status Gizi

Gizi sangat erat kaitanya dengan kesehatan seseorang. Agar fungsi tersebut dapat bekerja dengan baik, jumlah zat gizi yang dikonsumsi seseorang harus sesuai dengan kebutuhan tubuh. Apabila tubuh mengkonsumsi zat gizi kurang dari kebutuhanya maka akan terjadi kasus gizi kurang, sebaliknya apabila jumlah zat gizi yang akan dikonsumsi berlebihan akan mengakibatkan tubuh kelebihan zat gizi (Supariasa et al. 2012).

Berdasarkan hasil penelitian diketahui sebagian besar ibu- ibu yang mempunyai balita dengan gizi kurang sebanyak $59,2 \%$. Penelitian ini sejalan dengan penelitian Putriet al.(2015) tentang ststus gizi balita di Puskesmas Wososalam II Kabupaten Demak mendapatkan hasil yang tidak jauh berbeda yaitu sebesar $39,2 \%$ balita di daerah tersebut mengalami status gizi kurang. Begitu juga denganhasil penelitian Carolin, et al. (2020) di Puskesmas Sukadiri Kabupaten Tangerang didapatkan bawa $24,7 \%$ balita mengalami gizi kurang.

Menurut asumsi beneliti bahwa, masih banyak balita yang memiliki status gizi kurang, karena kurangnya informasi dan pemahan ibu tentang status gizi balita.Tingkat pengetahuan terhadap sikap dan perilaku dalam memilih makanan, dapat dapat berpengeruh terhadap keadaan gizi seseorang.

\section{Status Gizi Balita}

Hubungan antara Pengetahuan dengan

Berdasarkan hasil penelitian dan hasil analis bivariat menunjukan bahwa ibu yang berpengetahun kurang yang balitanya mengalami gizi kurang $(67,2 \%)$, lebih rendah dengan ibu yang berpengetahuan baik yang mengalami kurang gizi sebanyak $(33,2 \%)$. Hasil uji stastistik diperoleh bahwa ada hubungan yang bermakna antara pengetahuan ibu dengan status gizi balita.

Hasil penelitian sesuai dengan teori bahwa pengetahuan yang ada pada manusaia tergantung pada tingkat pendidikan yang dipeoleh baik secara formal maupun informal, dimana tingkat pengetahuan akan memberikan pengerahu pada cara-cara seseorang memahami pengetahuan tentang gizi dan kesehatan. Pengetahuan tentang gizi seseorang berpengaruh terhadap sikap dan prilaku dan memilih makanan, yang pada akhirnya berpengaruh terhadap keadaan gizi seseorang. Tingginya tingkta pengetahuan seseorang maka diharpakan akan lebih baik juga keadaan gizinya, (Khosman, 2012).

Penelitian ini sejalan dengan dengan penelitian yang dilakukan oleh Fakhrurijal et al.(2012), dengan judul analisi faktor yang berhubungan dengan status gizi pada balita di Kelurahan Winori. Dari hasil dengan menggunakan uji chi square diperoleh $p$ value $0,029<0,005$ yang berarti terdapat hubungan bermakna antara pengetahuan dengan kejadian status gizi. Sama halnya yang dilakukan oleh Himawan, (2017) dengan hubungan karakteristik ibu dengan status gizi pada balita di Kecamatan Gunungpati Semarang. Dengan hasil uji $p$ value $=0,012<0,005$ yang artinya ada hubungan pengetahuan dengan status gizi pada balita.

Menurut asumsi peneliti bahwa dengan banyaknya pengetahuan yang rendah pada ibu dapat berdampak pada sikap dan perilaku ibu dalam memberikan makanan kepada balita, yang menimbulkan ketidak seimbangnya makanan bergizi yang dibutuhkan balita mempunyai status gizi kurang.Namun pada balita yang mempunyai gizi baik pun ibu juga memiliki tingkat pengetahuan yang rendah tentang status gizi.Hal ini mungkin dikarenakan balita sering diasuh oleh nenek atau pengasuhnya yang memiliki pengetahuan lebih baik tentang gizi dibandingkan ibunya sehingga balita tetpa dapat terpenuhi gizinya dengan baik meksipun ibunya memiliki pengetahuan yang rendah tentang gizi.Pengetahuan ibu yang baik tetapi status gizi kurang dikarenakan pada beberapa ibu memberikan makanan kepada anaknya bukan berdasarkan kebutuhan nutrisi yang harus terpenuhi.Sedangkan pengetahuan ibu yang tinggi dan memiliki status gizi balita yang baik disebabkan karena ibu mengerti pentingnya kualitas makanan yang diberikan.Sehingga balita tercukupi gizinya dengan baik.

\section{Hubungan antara Pendidikan dengan Status Gizi Balita}

Berdasarkan hasil penelitian menunjukan ibu yang berpendidikan rendah yang bayinya mengalami gizi kurang sebanyak $(68,8 \%)$, sedangakan ibu yang 
berpendidikan tinggi dan bayinya mengalami gizi kurang sebanyak (42,9\%). Hasil uji stastistik di adanya hubungan yang bermakna antara pendidikan dengan status gizi balita.

Tingkat pendidikan merupakan salah satu indikator sosial dalam masyarakat karena melalui pendidikan sikap tingkah laku manusia dapat meningkat dan berubah citra sosialnya.Pendidikan ibu merupakan modal utama dalam menunjang ekonomi keluarga, juga berperan dalam penyusunan makan keluarga serta pengasuhan dan perawatan anak.penyebab ada hubungannya adalah karena tingkat pendidikan ibu akan mempengaruhi sikap dan pola pikir ibu dalam memperhatikan asupan makanan balita mulai dari mencari, memperoleh dan menerima berbagai informasi mengenai pengetahuan tentang asupan makanan gizi balita sehingga akan mempengaruhi pemilihan makanan yang akan menentukan status gizi balitanya. Semakin tinggi tingkat pendidikan ibu maka semakin tinggi juga pengetahuan ibu tentang asupan makanan bagi balitanya dan semakin mudah ibu dalam mengolah informasi berkenaan dengan status gizi balitanya (Atmarita, 2012).

Hasil ini sejalan dengan penelitian sebelumnya yang dilakukan oleh Suryani (2017) yang menunjukan bahwa terdapat hubungan yang signifikan antara tingkat pendidikan ibu dengan status gizi balita dengan hasil uji statsistik $p$ value $=0,012<0,005$.

Menurut asumsi peneliti dari penelitian dan penelitian terdahulu peningkatan tingkat pendidikan akan mempermudah seseorang menerima informasi, termasuk informasi gizi dan kesehatan sehingga dapat meningkatkan pengetahuan gizi dan kesehatan yang selanjutnya akan menimbulkan sifat yang positif dibidang kesehatan. Keadaan ini akan mencegah masalah gizi yang tidak diinginkan.

\section{Hubungan antara Pendapatan Keluarga dengan Status Gizi Balita}

Berdasarkan hasil penelitian dan hasil analis bivariat menunjukan bahwa pendapatan keluarga rendah yang mengalami gizi kurang sebanyak 39 orang $(70,9 \%)$, sedangkan tingginya pendapatan keluarga yang mengalami gizi kurang sebanyak 6 orang $(28,6 \%)$ Hasil uji stastistik di peroleh bahwa ada hubungan yang bermakna antara pendapatan keluarga dengan status gizi balita.

Hasil penelitian ini sejalan dengan penelitian yang dilakukan oleh Oktavianis (2016), dengan judul faktor-faktor yang berhubungan dengan kejadian gizi kurang pada balita dipuskesmas lubuk Kilangan. Dari hasil analisa diperoleh $P$ value $0,00<0,05$ yang berarti terdapat hubungan bermakna antara pendapatan keluarga dengan kejadian gizi kurang pada balita di Puskesmas Lubuk Kilangan Kota Padang. Hasil yang sama juga dilakukan oleh (Monikaet al.2014), dengan judul faktor-faktor yang berhubungan dengan kejadian gizi kurang pada balita dipuskesmas kecamatan cengkareng. Dari hasil analisa dengan menggunakan uji chi squere diperoleh $P$ value $0,02<0,05$ yang berarti terdapat hubungan bermakna antara pendapatan keluarga dengan kejadian gizi kurang pada balita dipuskesmas kecamatan cengkareng. Status ekonomi erat kaitannya dengan daya beli dalam keluarga. Status ekonomi seseorang dipengaruhi oleh pendapatan orang tersebut. Semakin tinggi tingkat pendapatan responden, maka akan semakinmberaneka ragam makanan yang dikonsumsi dan akan semakin baik pula nilai asupan makanan (energi) dari balitanya Oktavia, et.al (2017).

Menurut asumsi peneliti, pendapatan keluarga rendah dengan status gizi balita kurang mempengaruhi perubahan konsumsi kebutuhan keluarga.Sedangkan pendapatan keluarga rendah dengan status gizi baik dikarenakan meningkatnya pendapatan yang berarti memperbesar peluang untuk membeli makanan dengan kualitas dan kuantitas yang lebih baik. Namun sebaliknya penurunan pendapatan akan menyebabkan penurunan dalam hal kualitas makanan yang dibeli. Pendapatan keluarga yang tinggi dengan status gizi balita kurang disebabkan kerena jumlah anggota keluarga yang banyak sehingga kualitas pangan yang tersedia tidak memadai, dan banyaknya kebutuhan dalam keluarga yang harus dipenuhi, sedangkan pendapatan keluarga yang tinggi dan status gizi balita baik disebabkan karena tingkat ekonomi dalam keluarga yang menunjang.

\section{Hubungan antara Pekerjaan dengan Status Gizi Balita}

Berdasarkan hasil penelitian bahwa menunjukan bahwa ibu yang tidak bekerja dan balitanya mengalami gizi kurang sebanyak 29 orang $(64,4 \%)$, sedangkan ibu yang tidak bekerja dan balitanya mengalami gizi kurang sebanyak 16 orang $(35,6 \%)$. Hasil uji stastistik menunjukan tidak ada hubungan yang bermakna antara pekerjaan dengan status gizi balita.

Berdeda dengan teori bahwa ibu yang tidak bekerja dalam keluarga dapat mempengaruhi asupan gizi balita karena ibu berperan sebagai pengasuh dan pengatur konsumsi makanan anggota keluarga. Ibu yang bekerja tidak memiliki waktu yang cukup untuk mengasuh dan merawat anaknya sehingga anaknya dapat menderita gizi kurang 
(Himawan,2017). Kehidupan ekonomi keluarga akan lebih baik pada keluarga dengan ibu bekerja dibandingkan dengan keluarga yang hanya menggantungkan ekonomi pada kepala keluarga atau ayah. Kehidupan ekonomi keluarga yang lebih baik akan memungkinkan keluarga mampu memberikan perhatian yang layak bagi asupan gizi balita (Supariasa, 2012)

Hasil penelitian ini sejalan dengan penelitian yang dilakukan oleh Himawan (2017), dengan judul berhubungan antara karakteristik dengan kejadian gizi kurang pada balita Kecamatan Gunungpati Semarang. Dari hasil analisa diperoleh $P$ value 0,064> 0,05 yang berarti terdapat hubungan bermakna antara Pekerjaan dengan kejadian gizi kurang pada balita.

Menurut asumsi peneliti bahwa dampak negatif yang dikhawatirkan timbul sebagai akibat dari keikutsertaan ibu-ibu pada kegiatan di luar rumah adalah keterlantaran anak terutama anak balita, padahal masa depan kesehatan anak dipengaruhi oleh pengasuhan dan keadaan gizi sejak usia bayi sampai anak berusia 5 tahun merupakan usia penting, karena pada umur tersebut anak belum dapat melayani kebutuhan sendiri dan bergantung pada pengasuhnya. Oleh karena itu alangkah baiknya balita yang ditinggalkan dapat dipercayakan kepada pengasuh atau anggota keluarga yang lain untuk dirawat dan diberi konsumsi makanan yang baik.

\section{Hubungan antara Riwayat ASI dengan Status Gizi Balita}

Berdasarkan hasil penelitian menunjukan bahwa ibu yang tidak memberikan ASI dan balitanya mengalami gizi kurang sebanyak 39 orang $(72,2 \%)$ sedangkan ibu yang memberikan ASI dan balita mengalami gizi kurang sebanyak 6 orang $(27,3 \%)$. Hasil uji stastistik menunjukan bahwa ada hubungan yang bermakna antara riwayat ASI dengan status gizi balita.Beberapa penelitian telah membuktikan bahwa bayi yang diberi ASI ekslusif menunjukan perkembangan sosial dan kognitif yang lebih baikdari bayi yang diberi susu formula (Allison, 2015).

Hasil penelitian ini sejalan dengan penelitian yang dilakukan oleh Oktavianis (2016), dengan judul faktor-faktor yang berhubungan dengan kejadian gizi kurang pada balita dipuskesmas lubuk Kilangan. Dari hasil analisa diperoleh $P$ value $0,034<0,05$ yang berarti terdapat hubungan bermakna antara Riwayat ASI Ekslusif dengan kejadian gizi kurang pada balita di Puskesmas Lubuk Kilangan Kota Padang. Penilitian yang sama juga dilakukan oleh Monika (2015), dengan judul faktor-faktor yang berhubungan dengan kejadian gizi kurang pada balita dipuskesmas kecamatan cengkareng. Dari hasil analisa dengan menggunakan uji chi squere diperoleh $P$ value $0,048<0,05$ yang berarti terdapat hubungan bermakna antara ASI Eksklusif dengan kejadian gizi kurang pada balita dipuskesmas kecamatan cengkareng. Begitu juga dengan penelitian yang dilakukan oleh Lastanto (2015) didapatkan hasil $p$-value 0,038 yang berarti ada hubungan antara pemberian ASI dengan kejadian balita gizi kurang di wilayah kerja Puskesmas Cebongan.

Menurut asumsi peneliti, bayi yang tidak mendapat ASI eksklusif tidak mendapatkan kandungan nutrisi dalam ASI secara penuh sehingga kekebalan tubuhnya akan lebih rendah yang berdampak akan lebih mudah terserang penyakit. Dimana hal ini akan mempengaruhi status gizi balita.sebagian besar ibu tidak mengetahui waktu yang tepat dalam pemberian ASI eksklusif. Beberapa juga berpendapat bahwa pemberian ASI juga bisa ditambah dengan memberi air putih dan makanan yang lain seperti pisang. Sedangkan balita yang tidak mendapatkan ASI Eksklusif dengan status gizi balita yang baik dikarenakan selain ASI Eksklusif balita juga diberikan

\section{Hubungan antara Riwayat Penyakit Infeksi dengan Status Gizi Balita}

Berdasarkan hasil penelitian dan hasil analis bivariat menunjukan bahwa responden yang pernah menderitai riwayat penyakit infeksi serta dirawat di rumah sakit 3-4 kali dapat menyebabkan gizi kurang pada balita sebanyak 37 orang $(68,4 \%)$, sedangkan yang tidak pernah menderita riwayat penyakit infeksi yang menyebabkan status gizi kurang pada balita sebanyak 8 orang $(36,4 \%)$. Hasil uji stastistik menunjukan bahwa adanya hubungan yang bermakna antara riwayat penyakit infeksi dengan status gizi balita

Balita yang sering mengalami sakit atau infeksi lebih berisiko mengalami gizi kurang.Antara kecukupan gizi dan penyakit infeksi terdapat hubungan sebab akibat yang timbal balik dan sangat erat.Gizi buruk menyebabkan mudahnya terjadi infeksi karena daya tahan tubuh yang menurun. Sebaliknya pula dampak infeksi yang dialami akan mengakibatkan nafsu makan yang menurun dan penyerapan zat gizi yang terganggu yang pada akhirnya dapat menyebabkan balita mengalami gizi kurang dan gangguan pertumbuhan. Menurut Adriani dan Wirjatmadi (2014) infeksi bisa berhubungan dengan gangguan gizi melalui beberapa cara, yaitu memengaruhi nafsu makan, menyebabkan kehilangan bahan makanan karena muntah/diare, atau memengaruhi metabolisme makanan. Gizi 
buruk dan infeksi, keduanya dapat bermula dari kemiskinan dan lingkungan yang tidak sehat dengan sanitasi buruk.

Hasil penelitian ini sejalan dengan yang dilakukan oleh Hidayat, et,al (2012), dengan judul Analisis Faktor-Faktor Yang Mempengaruhi Kejadian Gizi Buruk pada Balita Di Kabupaten Kebumen Tahun 2012. Yang mengatakan terdapat pengaruh antara penyakit infeksi pada balita dengan kejadian gizi kurang pada balita.Penyakit infeksi yang sering terjadi pada anak-anak adalah diare dan ISPA.Diare dapat menyebabkan anak tidak mempunyai nafsu makan sehingga terjadi kekurangan jumlah makanan dan minuman yang masuk ke dalam tubuhnya yang dapat menyebabkan gizi kurang. Uji statsistik dengan nilai $p$ value $=0,023$ $<0,05$. Hasil yang sama juga dilakukan oleh Putri, et.al (2017) bahwa ada hubungan Penyakit Infeksi dan Pola Makan dengan Kejadian Status Gizi Kurang berdasarkan BB/U pada Balita Usia 6-24 Bulan di Wilayah Kerja PuskesmasTanah Sepenggal, dengan nilai $p$ value $=0,034$. Begitu pula dengan hasil penelitian Handayani (2017) yang menyatakan ada hubungan bermakna antara riwayat penyakit infeksi dengan status gizi pada anak balita dengan nilai $p=$ 0,001 .

Menurt asumsi peneliti bahwa balita yang sering mengalami sakit atau infeksi lebih berisiko mengalami gizi kurang.Antara kecukupan gizi dan penyakit infeksi terdapat hubungan sebab akibat yang timbal balik dan sangat erat.Gizi buruk menyebabkan mudahnya terjadi infeksi karena daya tahan tubuh yang menurun. Sebaliknya pula dampak infeksi yang dialami akan mengakibatkan nafsu makan yang menurun dan penyerapan zat gizi yang terganggu yang pada akhirnya dapat menyebabkan balita mengalami gizi kurang dan gangguan pertumbuhan.

\section{KESIMPULAN}

Hasil penelitian maka dapat disimpulkan bahwa dari 76 balita dengan gizi kurang sebanyak $59,2 \%$, ibu berpengetahuan kurang baik (76,3\%), ibu berpendidikan rendah $(63,2 \%)$, pendapatan keluarga rendah $(72,4 \%)$, ibu yang tidak berkerja $(55,3 \%)$, ibu yang tidak memberikan ASI $(71,1 \%)$ dan balita yang memiliki riwayat penyakit infeksi $(71,1 \%)$. Serta dari hasil penelitian terdapat hubungan yang bermakna antara pengetahuan ibu, pendidikan, pendapatan keluarga, riwayat $\mathrm{ASI}$, dan riwayat penyakit infeksi dengan status gizi balit sedangkan pekerjaan ibu tidak berhubungan dengan status gizi balita.
Sarannya diharapkan kepada petugas kesehatan dapat memberikan edukasi mengenai gizi kepada ibu agar lebih memperhatikan status gizi balitanya sehingga dapat meningkatkan derajat kesehatan.

\section{DAFTAR PUSTAKA}

Adriani, M., Wirjatmadi, B. (2014). Gizi dan Kesehatan Balita: Peranan Mikro Zinc Pada Pertumbuhan Balita.

Allison, Michael., \& Kaye, Jude. (2015). Strategic Planning for Nonprofit Organizations A Practical Guide for Dynamic Times Third Edition. New Jersey: John Wiley \& Sons, Inc.

Cakrawati, D., \& Mustika, N. H. (2012). Bahan pangan, gizi dan kesehatan. Bandung: Alfabeta.

Carolin, B. T., Saputri, A. R., \& Silawati, V. (2020). Analisis Faktor Yang Mempengaruhi Status Gizi Balita (12-59 Bulan) Di Puskesmas Sukadiri Kabupaten Tangerang Tahun 2018. IImu dan Budaya, 41(66).

Dinas Kesehatan Ambon. (2020). Laporan Rutin Bulanan Gizi Tahun 2020.

Fakhrurijal, D., Darmono, S. S., \& Basuki, R. (2012). Analisis Faktor-Faktor yang Berhubungan dengan Status Gizi pada Balita di Posyandu Mawar RW 05 Kelurahan Wonodri. Jurnal Kedokteran Muhammadiyah, 1(2).

Handayani, R. (2017). Faktor-faktor yang berhubungan dengan status gizi pada anak balita. Jurnal Endurance: Kajian IImiah Problema Kesehatan, 2(2), 217-224.

Hidayat, Y., \& Asrin, S. (2011). Analisis faktor-faktor yang mempengaruhi kejadian gizi buruk pada balita di Kabupaten Kebumen tahun 2010. J IImiah Kebidanan, 3(2).

Himawan, A. W. (2006). Hubungan Antara Karakteristik Ibu dengan Status Gizi Balita di Kelurahan Sekaran Kecamatan Gunungpati Semarang. Doctoral dissertation. Universitas Negeri Semarang.

Kementerian Kesehatan RI (2012). Pedoman Gizi Seimbang. Jakarta: Kementerian Kesehatan $\mathrm{RI}$

Kementrian Kesehatan RI. (2018). Profil Kesehatan Indonesia 2018. Jakarta: Kemenkes RI.

Khomsan, A. (2012). Ekologi masalah gizi, pangan, dan kemiskinan. Alfabeta.

Monika, R. L., Dewi, L., Susilo, W. H. (2014) FaktorFaktor Yang Berhubungan Dengan Kejadian Gizi Kurang Pada Balita Dipuskesmas Kecamatan Cengkareng Jakarta Barat 2014. Artikel IImiah. STIK Sint Carolus Jakarta

\section{SARAN}


Oktavianis (2016). Faktor-Faktor Yang Berhubungan

Dengan Status Gizi Pada Balita Di Puskesmas Lubuk Kilangan: Stikes Bukutinggi. Jurnal Human Care. 1(3)

Oktavia, S., Widajanti, L., \& Aruben, R. (2017). Faktor-faktor yang Berhubungan dengan Status Gizi Buruk pada Balita di Kota Semarang Tahun 2017 (Studi di Rumah Pemulihan Gizi Banyumanik Kota Semarang). Jurnal Kesehatan Masyarakat (eJournal), 5(3), 186-192.

Putri, M. S., Kapantow, N., \& Kawengian, S. (2015). Hubungan antara riwayat penyakit infeksi dengan status gizi pada anak batita di Desa Mopusi Kecamatan Lolayan Kabupaten Bolaang Mongondow. eBiomedik, 3(2).
Putri, R. F., Sulastri, D., \& Lestari, Y. (2015). FaktorFaktor yang Berhubungan dengan Status Gizi Anak Balita di Wilayah Kerja Puskesmas Nanggalo Padang. Jurnal Kesehatan Andalas, 4(1).

Riskesdas. (2018).Riset Kesehatan Dasar. Jakarta: Kementrian Kesehatan RI

Supariasa. (2012). Penilaian Status Gizi. Jakarta: ECG.

Suryani, L. (2017). Faktor Yang Mempengaruhi Status Gizi Balita Di Wilayah Kerja Puskesmas Payung Sekaki. Jomis (Journal Of Midwifery Science), 1(2), 47-53.

WHO (2017) Nutrition Landscape Information System (NLIS) Country Profile Indicators,.Interpretation Guide, editor. Switzerland: WHO Press. 